\title{
A Phenomenology Approach: Religious Significance of Mandala in Ancient Nias Culture
}

\author{
Sonny Eli Zaluchu' ${ }^{1}$ and Fransiskus Irwan Widjaja ${ }^{2}$ \\ \{sonnyzaluchu@stbi.ac.id ${ }^{1}$ \} \\ ${ }^{1}$ Indonesian Baptist Theological School (STBI) Semarang, Indonesia \\ ${ }^{2}$ Batam REAL Theological College, Indonesia
}

\begin{abstract}
Abstarct. Mandala is one of the cultural and religious symbols. They found in various ancient cultures. One of them is in the culture of the community on the island of Nias in northern Sumatra Indonesia. This article found that mandala is not just a traditional art or ornament. However, it is the theological reflection of a belief system that connects humans on earth with transcendent divine entities. Through it, ancient Nias people believed in the existence of divine reality in strong religious beliefs. The diagram also relates to the philosophy of life. The findings show that the craftsmen intentionally used various forms of diagrams as philosophical reflections of life which are believed to be closely related to local wisdom. As a result of the change in the Nias belief system from animism to the monotheistic worship of God (Christianization of Nias), there was a shift in the meaning of the mandala into cultural icons and ornaments. This paper written with a review of the literature analysis using the Phenomenology of Religion theory approach, starting from a discussion of the concept of the Indian in ancient cosmology to its symbolic meaning in the religious system. They have compiled with literature analysis using the Phenomenology of Religion theory approach.
\end{abstract}

Keywords: mandala, culture, symbol, Nias, religion system

\section{INTRODUCTION}

Cosmology is closely related to the building of human culture. Therefore the interpretation of cosmology can be started by analyzing cultural products produced by a group of humans. For example Borobudur Temple, located in Central Java, Indonesia. Borobudur is one of the most significant Buddhist cultural heritage buildings. King Smaratungga built this enormous temple between 780 and $830 \mathrm{BC}$ [1]. The study of this temple by Situngkir proved that the building of Borobudur temple was arranged in a symmetrical form and obeyed geometric laws [2]. When viewed from above, a symmetrical pattern formed from the large building which explains the philosophical concepts of Buddhist teachings. Wayman put forward the theory that the pattern is a large mandala pattern that symbolizes the concept of cosmology and philosophy in the teachings of Buddhism itself [3]. When viewed from a height, the terrace is arranged to form three divisions of the mandala. Sena explained that the three patterns are closely related to Buddhist cosmology, namely Kamadhatu (human world in the form of desire at the most basic level), Rupadhatu (the world seen in form), and the last Arupadhatu (supernatural and supreme 
world, which surpasses all natural forms) [4]. Like Borobudur, Mandala with a philosophical content of religion can found in various other cultures. One of them was found in ancient Nias culture as seen by Hammerle's research reported in his book entitled The Origin of the Nias People [5]. This tribe located on an island on the west coast of northern Sumatera, Indonesia.

Mandalas in Nias culture form diagrams that form concentric circular patterns with angular images. The average consists of sixteen angles. Sometimes it looks like a leaf pattern in a circle, which arranged symmetrically. Although it does not have nine angles as enneagrams in general, the pattern shown by the Nias mandala diagram has a universal resemblance to other cultural mandala diagrams like Borobudur. The picture below is the findings of the Mandala Nias revealed by Hämmerle in his book entitled The Origin of the Nias Community [5].

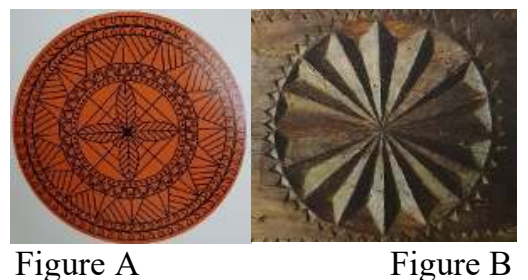

Fig. 1. the findings of the Mandala Nias revealed by Hämmerle in his book entitled The Origin of the Nias Community

(Source: J. M. Harmmerle, Asal Usul Masyarakat Nias. Gunungsitoli, Nias: Yayasan Pusaka Nias, 2001)

The first pattern (Figure A) is a mandala found as a diagram engraved in a hat (Nias: Takula) made of gold (Nias: Emas). In Nias language, it is called Takula Ana'a. While the second pattern (Figure B) and other similar, was found in the form of carvings in traditional and carved houses at the village gate. Image $\mathrm{A}$ is found in Nias in the northern part while picture B scattered in the houses and traditional villages of South Nias. Takula Ana'a is a typical Nias hat that is very rare. Made of gold and only used for the benefit of traditional events by noble groups in North Nias. The existence of the hat is very rare as the actions of the owners who sell or melt the gold into other jewelry. Hämmerle obtained the picture from Takula Ana'a from the duplication made by a gold craftsman in Gunungsitoli City who received a request to merge Takula Ana'a from a Nias resident who inherited the object, to become various gold jewelry. Meanwhile, the diagram engraved on South Nias traditional houses and carvings in several places such as Megalith stone and village gates can still see today.

If carefully examined, the symbols, images, patterns, and diagrams found in the development of ancient culture, it turns out to have a universal side in terms of form and meaning of cosmology. Philosophy and local wisdom provide a distinct theological weight in each symbol from different cultural backgrounds. This paper prepared to explore the meaning of the mandala diagram in Takula Ana'a and the Traditional Houses of the Nias Community. The main objective is to explore and express the religious significance of these symbols in the context of Nias culture.

\section{METHOD}

This article compiled through a literature method that uses primary sources (references about mandalas) and secondary (cultural analysis, religious sociology, and 
other complementary literature) [6]. The analysis begins by presenting the concept of the mandala. It followed by an analysis of the mandala symbols found on gold hats and traditional houses and their relation to the concept of primitive Nias cultural cosmology. In the end, the discussion uses the phenomenological approach of religion directed to explore the meaning of the Mandala in the cosmology and religious system of the ancient Nias people and the shift in meaning that occurred. The approach using the theory of religious phenomenology from Dhavamony [7] and Geertz [8] used as the main handle.

\section{RESULT AND DISCUSSION}

\subsection{Mandala Concept}

The diagram in Takula Ana'a and Rumah Adat Nias Community is a philosophical symbol called mandala. Online KBBI defines mandalas in two senses. First, the term that refers to the scope of religious power; Second is a picture in the form of a circle that can also translate as an environment (region or region) [9]. This term comes from Sanskrit which commonly used as a symbol of cosmology in Buddhism and Hinduism. Each religion has a concept. It can concluded that, although means circle, mandalas contain full theological meanings. The meaning of the meaning depends on the cultural scope that gave birth the mandala itself. As seen in the Borobudur temple mandala and related to the philosophical Buddhist religion, so does the mandala that emerges from the cultural concept of the Nias community, closely related to the tribal religion. Although the meanings vary, there are similar forms and visual diagrams. Each mandala arranged in concentric shapes and geometric patterns[10].

\subsection{Description of the Diagram of Takula Ana'a and Traditional House}

The diagram seen in Takula Ana'a has a concentric pattern. That is, there are many circles arranged in such a way and centered on one central point in the center of the image. The structure consists of an outer circle, a middle circle, and an inner circle. The outer circle is composed of ferns (diplazium esculentum) known as the 'böi' by Nias people. This plant readily found throughout the land and forest in Nias. It grows because fertile soil structures support it. In addition to the shoots consumed as food, this fern shape inspired a pattern of sculpture and painting in some Nias artistic works. The circular shape describes a rotating and continuous life. It also represents a statement of the fertility of Nias land with a typical rainforest. The second circle is more accurately describe as sixteen pyramid tops arranged in a circle. Hämmarle gives a slightly different interpretation by saying that it is an image of the spearhead as a symbol of courage and strength[5]. Meanwhile, according to William, the triangle pattern of the Pyramid leads to the meaning of eternity[11].

In the third circle, Hämmerle describes it as a pair of images of a woman's breast symbolizing fertility. The symbol is known as Bowo Tora'a from the name Tora'a Tree which is known as one of the most flowering trees in Nias. However, it can also add that a woman's breasts are not merely talking about fertility but life, through breast milk which supplied as food for every baby.The center of this circle is a leaf consisting of four concentric sheets, which are often used by Nias people to become medicine, and media that symbolize blessings when parents pray for their children by splashing water from the leaves onto the bodies or heads of their sons[12].

The pattern that is not too complicated shown by the Mandala carvings found in traditional houses and stone carvings. However, it has similarities in terms of circles. This carving and sculpture are more than just a cultural ornament. The measurements found in a traditional Nias 
house in the village of Sifaoro'asi Ulu Hou (Figure B) prove the similarity with the Takula Ana'a diagram in terms of sixteen angles centered on a point in the center of the circle. Likewise, many patterns are still found in some parts of the traditional Nias house.

The mandala can also mean a region or region. In this sense, it can understand the reason for placing a mandala diagram in a traditional house or village gate. It became a kind of marker of the village area, part of the country (in Nias language called Öri) or the scope of some religious regions. In primitive times, Nias people lived in groups in separate villages. Each in Dalma is an independent region and is not connecting with village communities in other regions. Each village can compete with each other or be hostile, even conquer each other. The tradition of 'mengayau kepala' (the head) of the enemy or foreigners, who violated the boundaries of the territory by primitive Nias people revealed in the record of the adventures of Modigliani on Nias[13].

\subsection{The Cosmology of Mandala Nias}

Although contrary to the results of anthropological research, Nias people have their version in explaining their origin. In the oral tradition, the mythology of the origin of Nias people is said to originate from the sky of Tetehöli Ana'a, a location that is above Gomo. The first population of Nias according to this mythological version, was derived from Tetehöli Ana'a complete with the tools needed to live life. The oldest archaeological findings in the form of Megalith stones support Gomo's idea, as the oldest cultural center of Nias people.

Telaumbanua and Hummel support conclusions regarding the development of animism in the religious system of primitive Nias people. Even though it is rich in myth, primitive Nias people live in harmony with nature and acknowledge the existence of divine entities in the form of gods who inhabited places different from human geography and are in the sky above and in the world below. In this concept, Nias people see that the world consists of several levels[14]. That is evident from the mandala diagram of Takula Ana'a and the Nias Traditional House. Circles talk about the cosmic scope which is a place for life. The center of some models of the mandala was a divine entity which eventually when Christianity expanded Nias Island changed its attributes from god to God.

In other words, the mandala for the people of Nias is a collection of meanings in expressing their belief systems in a primitive manner. That was strongly supported by Geertz who said that culture supports the presence of a shared attitude of meaning. As an integral part of the Nias culture system, the presence of diagrams in Takula Ana'a and carvings/carvings in traditional Nias houses is an attempt to exchange cultural meanings. Geertz emphasizes that in a culture that formed in a particular society, socially consists of structures of meaning, in the form of a set of signs in which the community takes one action and lives in that meaning. There could be reproach so that the meaning finally removed[8]. Geertz's prophetic prophecy was finally proven. The identity of the diagram lost in the swallow of the current era and the mandala carving or carving sign changed its meaning into mere ornaments, as the conversion of the entire Nias island population into a new religious system. Similarly, the end of Buddhist-Hindu influence in ancient Javanese kingdoms along with the entry of Islam as a new religion.

\subsection{Theological Reflections: Religious Symbols}

Even though the framing of Mandala Nias is animism, using the Geertz approach, is seen that there is an attempt by primitive Nias people in expressing the meaning of their belief in supernatural elements or divine entities that are understood as protective entities and dominate everything. The entity is considered holy as a transcendent and immanent person. Dhavamony provides a critical argument that explains this concept. According to him, primitive society has 
a form of awareness of the holy, which is extraordinary and supernatural. This awareness is increased in a hierophany (apparition). Starting from the most basic such as stone, or tree or statue to the highest or divine entity. For example, a stone will remain as a stone. However, if the stone is interpreting as something sacred, then the quality increases[7]. Dhavamony sees that the power of spirituality does not lie in materiality, but the meaning of its existence in culture as Gertz put it.

If the concept applied in elevating the meaning of Mandala Nias, it would soon be seen the order of spirituality referred to by the Dhavamony above. The concentric circle in Takula Ana'a and Rumah Adat affirms the divine 'something' as the center of everything in life. Man moves from the outermost edge in his spiritual journey to the deepest level, the center of the Mandala. Haiken said that basically, humans are spiritual beings, who always intend to connect with the source of life. Look again at the explanation at the beginning of the paper where all the meanings of life in the Mandala Nias expressed starting from the outer edge to the center of the mandala. Two things become the scope. First, 'ascese' or personal effort trains itself regularly to be open and sensitive to the Divine touch and greeting and second, mystical, that is, various forms and stages of a personal encounter with the Divine[15], [16]. In other words, the Mandala of Nias is a way of primitive Nias people expressing meaning in their animism belief system.

\subsection{A shift in meaning}

Along with the end of the animism period in Nias and the emergence of modern Nias people who knew more advanced civilizations, as well as the success of efforts in European 'zending' in the spread of Christianity, Mandala Nias experienced a fundamental shift in meaning. People in North Nias no longer know Takula Ana'a, as a sacred object that is a tool for expressing spirituality and honor. The objects were finally smelted and sold into smaller jewelry. His worth shifted from meaning to material. Likewise, with diagrams that were carved or carved, it finally stopped at a mere concept of cultural ornamentation, which became a decoration in traditional houses and village gates.

The conclusion made by Geertz can explain this phenomenon. In the end according to Geertz, people are in a position to oppose the meaning that they embrace in the cultural system. However, Geertz is not entirely justified. The interaction of Christianity with Nias culture did produce a very violent cultural clash. However, the result of the clash was the birth of a new meaning in the spirituality of the Nias people. If previously it was centered on gods, now it changed to God. The Christian Worldview approach model designed by Niebuhr in his classic book entitled Christ and Culture can use as an analytical tool[17]. In the book, Niebuhr divides the five approaches in looking at the relationship between Christ and the Mandala of Nias as a product of Culture. First, Christ opposes culture (Christ against culture); Second, Christ as a culture (Christ of culture); Third, Christ above culture (Christ above culture); Fourth, Christ and culture as a paradox (Christ and culture in paradox); and fifth, Christ transforms culture. Among these five thinking insights, concerning the shift in the meaning of Mandala from religious symbols in primitive Nias culture, the third approach is more acceptable as an explanation. Through this approach, there is an effort to complement each other's culture with Christian revelations. An entity that is above culture, Christ and all existential meanings of God (God), can shift the meaning of the introduction in cultural entities.

\section{CONCLUSION}

Mandala is a symbol and cultural product. The shape varies depending on the culture that gave birth to it. The diagrams and images in them are not mere signs, but become a sign that has 
gained additional meaning. Because it appears in a variety of different cultures, the Mandala is rich in meaning[18]. So that interpreting the Mandala Nias by looking at its correlation with Mandala in the scope of other cultures, is very inappropriate. Community experience and the way of expression of the society in every culture are not the same. The mandala can only be understood hermeneutically in the cultural context in which the mandala was born.

The Mandala of Nias as a cultural product born and developed in local wisdom is present as part of the social-religious system in the cosmology of primitive Nias communities. Pictures and symbols are used as a step to identify the belief system in culture. These symbols come alive and are meaningful because they originate and used as part of life experiences in the world. That is what initially made Mandala Nias something valuable and sacred.

The symbols and diagrams displayed in Mandala Nias have philosophical meanings which are expressions of belief in supernatural entities, which are Holy, supreme and invisible, which understood as something transcendent. Through diagrams, humans help themselves understand these entities in the immanent physical (material) world. Also, the relationships described in it represent the beliefs of human faith. For example, the symbol of fertility, courage, eternity is the meaning attached to the symbol as a philosophical grip and personal belief.

\section{REFERENCES}

[1] U. Hermawan, Budi; Rohman, Fatchur; Rahayu, Mintarti; Salim, "Borobudur Temple as Buddhist Pilgrimage Destination in Indonesia: an Analysis of Factors that Affect Visit Intention," J. Int. Buddh. Stud., vol. 7, no. 2, pp. 98-110, 2016.

[2] H. Situngkir, "Borobudur Was Built Algorithmically," 2010.

[3] A. Wayman, "Reflection on the Theory of Borobudur as a Mandala," in Barabudur, History and Significance of a Buddhist Monumenrt, Berkeley: Asian Humanities Press, 1981, pp. 139-172.

[4] I. G. M. W. Sena, "KONSEP KOSMOLOGI DALAM PERSPEKTIF AGAMA BUDDHA," Vidya Samhita J. Penelit., vol. 110, no. 1, pp. 110-124, 2015.

[5] J. M. Harmmerle, Asal Usul Masyarakat Nias Suatu Interpretasi, 1st ed. Gunungsitoli, Nias: Yayasan Pusaka Nias, 2001.

[6] C. L. Winchester and M. Salji, "Writing a literature review," J. Clin. Urol., vol. 9, no. 5, pp. 308-312, 2016.

[7] M. Dhavamony, Fenomenologi Agama, 9th ed. Yogyakarta: Kanisius, 2016.

[8] C. Geertz, "Agama Sebagai Simbol Kebudayaan," in Seven Theories of Religion, 2nd ed., D. L. Pals, Ed. Yogyakarta: IRCiSoD, 2012.

[9] "Mandala," Pusat Bahasa. .

[10] D. Harms, "Geometry of the Mandala," Jung J., 2011.

[11] B. Williams, Egypt's Making: The Origins of Ancient Egypt 5000-2000 BC, vol. 67, no. 1. 2008.

[12] R. Suradi, "Spesifitas Biologis Air Susu Ibu," Sari Pediatr., vol. 3, no. 3, p. 134, 2017.

[13] V. Puccioni, Tanah Para Pendekar: Petualangan Elio Modigliani Di Nias Selatan Tahun 1886. Jakarta: Gramedia Pustaka Utama, 2016.

[14] U. Hummel and T. Telaumbanua, "Cross and Adu: A Socio-Historical Study on the Encounter between Christianity and the Indigenous Culture on Nias and the Batu Islands, Indonesia (1865-1965)," Universiteit Utrecht, Nederlands, 2007.

[15] A. Haiken, Spiritualitas Kristiani. Jakarta: Yayasan Cipta Loka Caraka, 2002.

[16] C. Zwingmann, C. Klein, and A. Büssing, "Measuring Religiosity/Spirituality: Theoretical Differentiations and Categorization of Instruments," Religions, vol. 2, no. 3, pp. 345-357, 2011 
[17] R. Niebuhr, Christ and Culture. New York: HarperCollins Publishers, 2001.

[18] G. van Schie, Hubungan Manusia dengan Misteri Segala Misteri - Rahasia Dibalik kehidupan. Jakarta: FIDEI Press, 2008. 